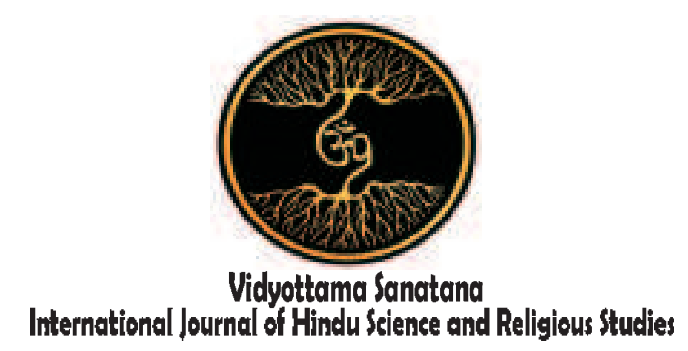

Vol. 1 No. 2 October 2017

\title{
Ngaben Conception In Lontar Siwa Tattwa Purana
}

\author{
By: \\ I Nyoman Kiriana \\ Institut Hindu Dharma Negeri Denpasar \\ E-mail: kiriana@ihdn.ac.id
}

\begin{tabular}{|l|l|l|}
\hline Received: August 20, 2017 & Accepted: September 15, 2017 & Published: October 30, 2017 \\
\hline
\end{tabular}

\begin{abstract}
Abstact
Generally, in most traditions every birth and death will be made a ritual. The implementation of these rituals will usually be adapted to the local culture. Thus in the implementation order will vary, but the substance is the same. In the tradition of the Hindu community in Bali, if there are people who died will be made Ngaben ceremony, as a form of respectful and responsibility. In the implementation of this Ngaben ceremony will always be guided by the sacred books and will be adapted to the local tradition. One of the sacred books guided in Ngaben's ceremony is Lontar Siva Tattwa Purana. In this Lontar explained that Ngaben ceremony is an obligation of his descendants as one of the payment of Rna (debt) to his ancestors. In practice it, must be adjusted to the level of ability of his or her generation for all harmony. Further, will be explained the procedure of Ngaben ceremony in this Lontar start from the beginning to the end.
\end{abstract}

Keywords: Tradition, Ngaben, Lontar Siwa Tattwa Purana.

\section{Introduction}

Traditionally, almost all religions in the world believe that the universe and its contents are created by God. All that is created will return to it, because the most certain of this life is death. Generally in most of the religions, when someone is death will be made a ritual in according to the tradition that has been passed down from generation to generation. In various traditions related to the corpse there are some of them in the grave and some are burned.

In the beliefs of the Abraham religions (Jews, Christians and Muslims), most of the corpses were in the grave, but in Hinduism the corpses were generally burned. The burning of the body in Hinduism is mainly equipped with various means of banten which has its own meaning and function. Implementation of the process of the corpse in Hinduism in Bali will be always referring to the traditions and the 
texts related to it. This causes the implementation of the ritual of the corpse will be vary in its implementation.

Lontar Siwa Tattwa Purana is a lontar that contains instructions for Hindus in the implementation of Ngaben ceremony from the level of Nista, Madya and Utama, which is implemented in accordance with the level of caste as well as the final gratitude to the parents or ancestors, so it can be used as an orientation and guidance in performing Ngaben ceremony.

Along with the development of the era and the rapidly growing of globalization, the implementation of Ngaben ceremony, especially carried out by the Hindu community in Bali and outside of Bali is changes so much and various forms of variation in its implementation. In the procession of bringing the corpse to the cemetery which was once almost all carried together, but now there are many containers (place of corpse) that uses the wheels and even transported by car.

\section{Result and Discussion}

\subsection{Description of Lontar Siva Tattwa Purana}

Lontar Siwa Tattwa Purana is a classic literature work derived of original lontar from Jero Kanginan Sidemen Karangasem, then translated by I Gede Sura, I Gusti Ayu Rai Arnita and the team and then collected by the Provincial Culture Office of Bali with the number of pages consisting of 20 pieces, length $43 \mathrm{~cm}$ and $3.5 \mathrm{~cm}$ wide. This Lontar circumstances are well preserved because there are special employees in the Provincial Culture Office of Bali who are employed to treat the papyrus (Lontar) in order this cultural heritage is not extinct eaten by age.

If it viewed in terms of language and background of culture, this text seems to be written in Bali in the middle of Bali era. This text can be regarded as a minor text which its content comes from some older texts. The original language of Lontar Siwa Tattwa Purana script is using the Balinese script, which is documented by the Cultural Office of Bali Province. The first translator in Kawi (Bahasa Jawa Kuno) was performed on June 3, 1998, by I Made Subandia. Kawi language that is used as a medium, absorb many cultural terms and vocabulary of Bali language. The language structure is poorly maintained. The social structure of traditional Balinese society is very dominant in determining the different system of ceremonial execution that is taught.

Lontar Siwa Tattwa Purana is one of the many papyruses that contain the teachings of Hinduism that are Shiva. Lord Shiva teaches the Events of Religion lesson to His sons. This doctrine is spelled out by means of dialogue and speechs in 20 pieces of papyrus. Basically Siwa Tattwa Purana lontar contains instructions on the implementation of Pitra Yajna, from Atitiwa to Angluwer conveyed by Sanghyang Jagatpati (Sanghyang Girinata) to His sons namely the gods. Besides it also mentioned the name of the day, wuku, sasih, date, and pangglong is the embodiment of the Gods. The day, wuku, sasih, date and panglong are so good as a clan for every execution of a yajna or a ceremony.

\subsection{Ngaben Conception in Lontar Siwa Tattwa Purana}

God is the greatest creator. Everything in this world is His creation. As well as plants, animals, and also including humans. Human was created by God into this world in order to do as much good for the benefit of dharma and to defend the truth that comes from the teachings of the Hindu religion of the Vedas (Sukrawati and Wandri, 2010: 89). Humans live always in the community and live together. Humans cannot live alone and always depend on each other because humans are social beings that require a friend in his life.

The Hindu community life is imbued by Hinduism with religious concepts written in the 
lontar. The Hindu community, especially in Bali, which is famous for its culture and as a dive for Hindu literature, keeps many of the Hindu literature in the form of papyrus. Lontar or manuscripts mostly contain the teachings of tattwa, ethics and ritual which are the three basic frameworks of Hinduism. The sacred teachings contain advice that should be exercised in achieving the essence and purpose of life so that the birth of various teachings of dedication and ceremonies. The one concept of Hinduism teachings contained in Lontar Siwa Tattwa Purana is Ngaben ceremony.

Ngaben ceremony begins with yadnya, yadnya means worship, sacrifice both material and non material based on a sincere heart and pure holy for noble purposes. In Sanskrit English Dictionary and Webster Dictionary explained that yadnya (yajña) means sacrifice (Balinese ceremony), while the sacrifice means the act of offering the life of a person or animal, or some object, in propitiation of or homage to a deity. Sacrifice performed by human beings are actions or behaviors of offerings that aim to draw closer to the gods. By performing the sacrifice, it is implied that something is expected or appealed to God that tends to be the welfare of life, so that the implementation of the offering is generally a religious ritual as a form of devotion to Him. The meaning of yadnya is all forms of sacrifice with sincere and from a pure heart for the purposes of noble. One of yadnya commonly performed in the form of offering is in the form of ritual, both to God, human and also its environment (Tri Hita Karana), whereas in all activities of human life, yadnya realized in the form of sacrifice either in the form of mind, word or behavior (Tri Kaya Parisudha ). Finally, yadnya (sacrifice) is not just a ritual, but every sacrifice is called yadnya, so ritual is one form of sacrifice (yadnya).

Ngaben ceremony is a sincere sacred sacrifice directed to the ancestors and parents, such as: memukur ceremony, ritual ceremony of soul and respect for the parents. In the
Kekawin Niti Sastra, IX.2 affirms the following human obligations:

"Kramaning dadi wwang ana ring bhuwana pautanganta ring praja, ri sirang munindro nguniweh the atiti gamaneka sambraman, athawa muwah wapday rahyang amara rena yogya kingkingen, panahurta ring pitara potraka luputakening yamalaya"

Translation:

"Man on this earth has a duty to his fellowman. The holy person, let alone the guests, is to be treated with respect, especially our obligations to parents, saints, and gods, should always be remembered, as our children are obliged to release our ancestors from the residence of Bhatara Yama "( Sukrawati and Wandri, 2010: 90).

In the teachings of Hinduism a child in his life should be able to do something to his parents, its mean being respectful, loving and protecting while alive, but also must help and save the spirits of ancestors or parents of hell (suffering). This can be seen in the excerpt of Lontar Siwa Tattwa Purana text, $3 \mathrm{~b}$ follows:

"Taham pwa nghulun. Hulun anakta Hyang Brahma, Wisnu. Tuhu pakulun yan amralina sarira. Atyanta kasyasih pinakanghulun masawa. Makaryya hulun padma lingganing sawa. Yan nora masawa pwanghulun, akaryya hulun reka lingganing taru mrik. Yatika ginawe padma. Abhusana sarwwa pethak. Magawe hulun panileman ri kala wwe hayu. Kinyecel sari lawan kajang sinurat kottamaning aksara. Kang sawa maturaken saji-saji ya”.

Translation:

"Yes lord servant. We are your Son, Hyang Brahma and Hyang Visnu. If you really want to destroy your body. How sad we are still incorporated this body. We will make Padma lingga as your body. If you do not leave the body, we will make Raka lingga of fragrant wood as a symbol of your 
body. He is the one who will make Padma decorated with white cloth. We will perform the ceremony of panileman on a good day, sprinkled with flowers and Kajang inscribed with the main, wise script. And we will offer offerings to your body (Team. 1998 p. 14).

In the life of society respect for parents or ancestors can be implemented and this means that the life of society is the arena to fulfill the obligation of life including here carrying out the ceremony Ngaben, the respect for parents and ancestors. One of the implementation of Ngaben ceremony as a form of respect and bhakti to parents and ancestors is to carry out the ceremony Ngaben. Ngaben ceremony is a level in a Pitra Yadnya ceremony. In the cremation ceremony which takes precedence is the restoration of human body to its original element that is Panca Maha Bhuta. Ngaben contains the meaning as a funeral ceremony to become ash. Ngaben ceremony is the completion of the corpse of the deceased the teachings of Hinduism (Sukrawati and Wandri, 2010 p 96). In lontar Siwa Tattwa Purana described about the implementation of ceremony Ngaben among others as follows:

"Singgih yan mangkana, kinaryya hulun badhe kang nista, madhyottama. Kang uttama atumpang-tumpang, hana overlapping miwah overlap sangha, sapta, pent overlap, opponent chess. Irika genahang sawa uttama. Anagha bandha ta haranya. Badhe winilet apindha Tatsaka. Ginawe bhusana nira amanca warnna. Dinulur lembu, badhusa, abale alung salunglung haranya genahing patulangan ".

"Munggah pwa nghulun ring bhade, mawa nghulu whip mesi romaning manuk dewatha. Outline mamargi ikang badhe mungsi setra. Hana among nga. Mawa artha sinekar ura. Dhatang $i$ catuspata, midher tang badhe ping three. Dhatang pwa ring setra, mwah midher ping three. Iniring tatabuhan, haraning gong, gambang mwang angklung. Wus mangkana sadhatanging setra, ginawa kang sawa bull ring. Irika binresihan dening tirta, kottama awadhah paruk mesi pangeleb, simsim masoca mirah, miwah paripih padha sinuratan haraning tirtha panglepasan, miwah tirtha widhi-widana. Wus mangkana basmikena kang sawa dening aghni. Petahulanya binresihan genahaken miwah weka apindha waktra, angga, hands, tribe, inugning taru sakti. Miwah pinupulaken ring dwegan niyuh dhanta. Bhusananen sarwwa pethak. Inayut dhatanging wwe agung "(Lontar Shiva Tattwa Purana, 4b).

Translation:

"Oh my Lord. If that is the case, we will create a small, medium and large Bade. The main bade is the bade on which the roof is occupied: there are eleven, nine, seven, five and four. That's where your main body place is. (Bade) that uses Nagabhanda is his name, the bade that is draped by a dragon as a symbolizing the Taksaka dragon. It decorated in five colors. Followed by Ox, Bandusa. Wearing bales called bale Alung-salunglung as a place of repetition ".

"The servant who will ride the bade, with a paw-tailed cuddly tail feathers. Bade was then carried to Setra, where burned bodies. There is a so-called Amanjang, the person who brought money (kepeng) sprinkled with flowers. After arriving at the intersection of the street, bade was carried around three times. And upon arrival in Setra again carried around three times. It accompanied by music: Gong, Gambang and Angklung. Upon reaching Setra, your corpse is placed on the body of the ox. 
Then purified by Tirta (holly water). The main Tirta is placed in the caldron that contains a ring with Ruby gems and golden slabs inscribed with the names of Tirta Panglepas and Tirta Widhi Widana. After that your body was burned with fire. The ashes are then collected and cleaned for re-formation of head, body, hands and feet. It crushes with dadap tree, taru Sakti. Then collected and embedded with Gading coconut shell. It decorate with a white cloth and finally washed down into the sea “(Team, 1998 p. 15).

From these translations can be explained that as Hindus have an obligation to perform Ngaben ceremony dedicated to the ancestors who has died as the final form of reverence and gratitude. As a child who is devoted to the parents or ancestors, is obliged to pay the debt (Rna) by running the correct Ngaben ceremony and in accordance with the ability. All facilities used, such as bade, ox, gambelan and so on are a manifestation of respect and devotion to parents and ancestors, and hope the implementation the ceremony of Ngaben can run well and in carrying out the ceremony Ngaben must be based on a sincere heart in accordance with religious teachings.

So the concept of Ngaben ceremony in Lontar Shiva Twawa Purana, 4b that explains about the means used in Ngaben ceremony in accordance with the level of nista, madya and utama. To respect and commemorate his services by organizing the ceremony of the body (Sawa Wedana) from the beginning to the last stage called Atma Wedana.

By performing the ceremony Ngaben show our obligations as a dutiful offspring (pertisentana). The manifestation of the gratitude can be realized by performing Ngaben ceremony that is adjusted to the level of nista, madya, utama and adapted to the desa, kala, patra. It is also found in Lontar Asta Kosali “Tukang Wadah" as follows:
"Muwah araning wadah utama, panganggen Brahmana, muwang Sang Satria, sane kari pada ulaka, liurnia padmanglayang, padma sari, padmasana, yaning malengkiang maileh, tur mabale-balean, tur mabajra, padma sari, nga"

"Muwah ana waranugrahan tumpang, antukida Sang Hyang Siwa ring Dalem, ana wanugrahan tumpeng, 11, ring Parbagus, ana waranugrahan tumpang 7, ring Wesia, anan waranugrahan tumpang 7, ring Bendesa, Prebekel Gede wang kawisuda, samangkana lingning aji, ayua amendungin pangangge watek Dewa, apan watek Dewa amiu salikur, mangkana kawruhakena, makalanlaning tukang" (Lontar Asta Kosali Tukang Wadah, $8 a)$.

Translation:

"And the name of the main container (uttama), for Brahmans and Ksatria, which is still walaka, among others: Padmanglayang, Padmasari, Padmasana, when melengkiang all and wear balebalean, and wear bajra, it is Padma sari his name".

"And there is grace overlaid (gift tumpang) by Ida Sang Hyang Siva in Dalem, there is grace overlaid (gift tumpang) 11 to Prabagus, there is grace tumpang (gift tumpang) 7 to wesia, there is grace tumpang 7 to Bandesa, Prabekel Gede, Kawisuda, so he said literature, do not match the clothes of the gods, because the gods wearing overlapping 21 it must be known, if they become carpenters "(Lintar, 2009 p. 62).

The implementation of Ngaben ceremony by using different types and forms of bade (tower) in the Hindu community in Bali as 
mentioned previously is also stated in Lontar Siva Tattwa Purana, $4 \mathrm{~b}$ as follows:

"Singgih yan mangkana, kinaryya hulun badhe kang nista, madhyottama. Kang uttama atumpang-tumpang, hana tumpang sawelas miwah tumpang sangha, sapta, tumpang panca, lawan catur. Irika genahang sawa uttama. Anagha bandha ta haranya. Bade winilet apindha Tatsaka. Ginawe bhusana nira amanca warnna. Dinulur lembu, badhusa, abale alung salunglung haranya genahing patulangan.

Translation:

"Oh my Lord. If that is the case, we will create a small, medium and large tower (bade). The main bade is the bade on which the roof is occupied: there are eleven, nine, seven, five and four. That's where your main body placed is. (Bade) that uses Nagabhanda is his name, the bade that is draped by a dragon symbolizing the Taksaka dragon. It decorated in five colors. Followed by Ox, Bandusa. Wearing bales called bale Alung-salunglung as a place of repetition "(Tim, 1998: 15).

Bade (tower) is a building for sawa (corpse). Material and size are very special. That is, the architecture of this object is very different from the architectural pattern of the building for the living human, especially those used for the gods. The use of bade shows one's social status in society. What kind of bade can and should be used by someone, determined based on his status in the society at that time. The higher of social status or position of a person in society, the greater the type of bade used. So that provision also means grace. But this rule is issued by the pastor as Sang Adi Guru Loka or Guru Pengajian as guidance of people in religious life. Rather the provision was issued by the king as Guru Wisesa. But the gift is wanted and continued to be inherited by the generation, although the grandchild did not inherit the function of his ancestors. The rules made by the king, namely the community in accordance with social status or position, may make a place of the corpse shaped padmasana or padmasari, bade and container. Shaped padmasana or padmasari may be used to carry the body of a priest or other priests. Because the pastor is Sang Adi Guru Loka or Guru Pengajian for people whose duty is devoted to the religious field. In Padmasana, the base there are badawangnala (sacred creatures such as turtles) and padmasari not use the animals are very purified it. While bade is a stretch of stretchers (bertumpang) complete with badawangnala as the base of the building. It also decorated with Boma (giant mask) and five-color cotton decoration. Bade (bertumpang) 11 is used for the body of the King of Bali (Gelgel Klungkung). The ninestory bade is used for the king's family or thes servant of king Bali. The seven-story bade is used for families whose ancestors once became punggawa and equal officials. The bade is a stretcher without badawangnala may be storied but wear boma decoration and limited cotton color. Bade is used by something citizens (clan). How many levels can make a container, it depends on the king's grace as stated in the chronicle (Kaler, 2008 p. 82).

The purpose of the implementation of this Ngaben ceremony is for the sincere devotion and devotion sincere, lifting and perfecting the position of ancestor spirits in the heaven. Paying attention to the interests of parents by realizing the sense of devotion, giving something good and worthy, respect and care for life in his old age also including the implementation of Yadnya. Therefore each yadnya is a sacred offering, sincerity in mind, word and deed (Tri Kaya Parisudha), as Lontar Dewa Tattwa gives the rule as follows:

"Kramaniya sang kumingkin akarya hayu, sanistha madhyottama, manah lega dadi hayu, ayuwa ngalemdrewya 
mwang kamungutan kaliliraning awing atua, ayua angambek rodra mwang ujar gangsul, ujar menek juga kavedar denira. Mangkana kramaning Sang ngarepang karya hayu, ayuwa simpangin budhi mwang rodra".

Translation:

"The ordinance for those preparing to execute yadnya in the form of nista, madya or utama. It should be based on a holy mind and sincere, do not be too fond of his possessions. Keep the behavior, do not talk harsh or angry. Good, sweet, pleasing words should be spoken. So that purity yadnya is the main goal. Disputes, dirty mind, angry berate, should be avoided. The mind, words and deeds that astiti bhakti are based on the sanctity of the heart that must be maintained to achieve common goals “(Lintar, 2009 p. 79).

Ngaben ceremony is a ceremony or ritual death of Balinese-Hindus people are distinguished between dead by tattwa by dying based on religious ceremonies. In the practice of Balinese society life in general is meant and understood as a ceremony Ngaben is a death ceremony by burning the bodies of people who have died (Kabayantini, 2013 p. 90). In the implementation of Ngaben ceremony Hindus in Bali have the types and rules. It is also contained in the Lontar Siva Tattwa Purana as follow:

"Mwah rengonakenanakKu, Yan hana wwang madhya padha pejah tan hana sawanya, tan inulatan. Ika wenang ginawe swastha. Mwah yan matyaprang, wenang amor ing Licin. Yan manusa masawa, tan wenang swastha. Yan purug, matemah sasal makweh. Matemah gagak ahusugan ngala-ngala ring nagara krama mwah nalu. Yan wwang salah patya, tar wenang upakara, hentyakena 3 tahu” (Lontar Siwa Tattwa Purana, 7a).
Translation:

"And listen, my child. If there is dead people does not leave the body wadag. Its Body Wadag is not seen, he should have made a Swastha ceremony. If any man dies in battle, he is entitled and can unite with the Sanghyang Licin. But if he dies and leaves the wadag body, he should not be married to the Swastha ceremony. If it is not noticed, that is what causes misery. Being a bad raven, it sounds noisy and disturbs the tranquility of the State. If the dead Salah Pati, he should not be ceremony before he was buried for three years “(Team, 1998 p. 17).

So, the concept of teaching Ngaben in Lontar Siva Tattwa Purana, 7a that explains the rules and types of Ngaben ceremonies. One of them is Ngaben Swasta, the Ngaben ceremony performed for people who died but there is no body. Likewise the rules for people who die unnatural (Salah Pati).

In addition to the Lontar Siwa Tattwa Purana, the types and rules in the implementation of the Hindu Ngaben ceremony in Bali are also contained in Lontar Tattwa Loka Kerti attachment 5a, whose contents that if the remains are not negated and only buried, it will cause a catastrophe or danger for both died, for the families left behind, for the people and the village.

"Yan mwang mati mapendem ring pertiwi salawasnya tang kinenam widi widhana, byakta matemahan roga ring bhuana, haro-haro gering merana rat, atemahan gad-gad...."

Translation:

"If the dead are graved on the ground, forever not Ngaben, actually will be a disease of the earth, disorder, sick, miserable in the world, become gad-gad (the body) ..." (Lintar, 2009 p. 80).

After the Ngaben ceremony implemented then the next Pitra Yadnya ceremony is 
Mamukur Ceremony, Maligia or Angluwer the highest level of Pitra yadnya ceremony. Mamukur ceremony is the last ceremony of Pitra Yadnya that must be implemented by Hindus. The mamukur ceremony has aims to purify the atma. After the Mamukur ceremony done then the title of Sang Pitara became Pitra Widhi, after Maligia changed the title to Widhi Wasa Pitara. After Angluwer called Acintya Pramanaya Pitara.

The implementation of Mamukur ceremony or Ngeluwer in Lontar Siva Tattwa Purana can be seen in quotation text as follow:

"Taham pwanakKu".

Mojar Sanghyang Gana lawan Sanghyang Uma, "Hulun ginawe bukur. Tar wenang wong camah, wong candhala, bhuta, tuli, kurang lewih, cedangga. Wong hayu wenang”. Mojar Hyang Indra lawan Hyang Samara, "Hulun ginawe ligya, nga. Tar wenang ing sor sarwwa kinaryya. Ginawe pwa ya panggungan, nga”.

Major mwah Sanghyang Bhayu mwang Sanghyang Bharuna, Sanghyang Kala lawan Sanghyang Suryya, prasama makabehan. "Singgih pakulun, hulun ginawe raja karyya angluwer namanya. Apan hulun kaping untat, tan hana kotamanya. Maka wenanging iwak sajisajinya: daging samudra miwah daging giri gahana, buron kidhang pethak, paksi sahaneng sucyalaksana. Wwe sarayu, Yamuna, Sindhu, Saraswati, mwang Gangga. Ika kottamaning tirta. Telas pwa sagatining raja karyya, dulurduluraning atiwa-tiwa" (Lontar Siwa Tattwa Purana, 6a).

Translation:

"Its okay my child ".

Sanghyang Gana and Sanghyang Uma said: "The servant who makes the Mukur ceremony. Not for dirty people. Defects Body, blind, deaf, not good. Only good people can be “. Hyang Indra and Hyang
Semara said: "The servant who made the Ligya ceremony. This ceremony should not be created below. Deservedly it maked panggungan “. Sang Bayu, Sanghyang Baruna, Sanghyang Kala, Sanghyang Surya and other gods said: "Yes our lord. We performed the Angluwer ceremony. Because we are the last, there is nothing more than this. The flesh of the offering is the content of the sea, the content of the land and the mountains: the white deer, the sacred bird of his deeds. The holly water used as the main tirta is the river water of Sarayu, Yamuna, Sindhu, Saraswati and river water of Gangga. Then finished the whole series of ceremonies called Ngaben “(Team, 1998 p. 16).

Finally, its the concept of Ngaben teaching contained in Lontar Siva Tattwa Purana. In the implementation of Ngaben ceremony described is from carrying out obligations as a child who is filial to parents or ancestors by carrying out Ngaben ceremony until the last ceremony of the Mamukur ceremony or also called Maligia or Angluwer ceremony.

\section{Conclusion}

Ngaben ceremony in Lontar Siwa Tattwa Purana is to explain about how to pay debt (Rna) to parents or ancestors by one way by performing the Ngaben ceremony, in accordance with the ability and is based on a sincere heart in accordance with religious teachings. By conducting the ceremony of the body (Sawa Wedana) from the beginning to the last stage adjusted to the level of nista, madya, utama and adapted to the desa, kala, patra.

The ngaben ceremony is the responsibility of children or descendants to parents or other families, because this ceremony is a duty and as a form of respect and devotion to parents and ancestors that is by carrying out the Ngaben ceremony. The implementation of Ngaben 
ceremony carried out by the children or the generation concerned as a form of gratitude and respect to parents and other families. As a child who devoted to parents or ancestors, obliged to pay the debt (Rna), one of them by making Ngaben ceremony. The rules of implementation of this ceremony, of course must be adjusted with the ability so as not to strengthen the life of his descendants in the future.

\section{References}

Dunia, I Wayan. 2009. Kumpulan Ringkasan Lontar. Surabaya : Paramita.

Kaler, I Gusti Ketut. 2008. Ngaben : Mengapa Mayat Dibakar?. Denpasar : Pustaka Bali Post.

Kebayantini, Ni Nyoman. 2013. Komodifikasi Upacara Ngaben di Bali. Denpasar: Udayana University Press.

Keriana, I Ketut. 2007. Prosesi Upakara \& Yadnya. Denpasar: Rhika Dewata.

Lintar, I Ketut. 2009. Wadah Dalam Upacara Ngaben Ngerit Bagi Masyarakat Hindu Di Bali (Kajian Bentuk, Fungsi Dan Makna). Skripsi (tidak diterbitkan). Jurusan Pendidikan Agama Hindu, IHDN Denpasar.
Ngurah, I Gusti Made, dkk. 1999. Agama Hindu Untuk Perguruan Tinggi. Surabaya : Paramita.

Sudarsana, I. K. (2017). Interpretation Meaning of Ngaben for Krama Dadia Arya Kubontubuh Tirtha Sari Ulakan Village Karangasem District (Hindu Religious Education Perspective). Vidyottama Sanatana: International Journal of Hindu Science and Religious Studies, 1(1), 1-13.

Sukrawati dan Wandri. 2010. Kaedah Beryajna. Surabaya: Paramita.

Sura, I Gede. 2006. Siwa Tattwa. Denpasar: Pemerintahan Propinsi Bali.

Tim Pusat Dokumentasi Kebudayaan Bali, 1998. Alih Aksara Lontar Siwa Tattwa Purana. Denpasar: UPD Propinsi Daerah Tingkat I Bali.

Tim penyusun, 2002. Kamus Istilah Agama Hindu. Denpasar : Pemda I Bali Denpasar.

Vaidya, L.R., 1980, The Standard SanskritEnglish Dictionary, Asian Publication Services, New Delhi India.

Victoria, Neufeldt, 1995, Webster's New World College Dictionary (Third Edition), Macmillan, USA. 